\title{
THE IMPACT OF ANTIEPILEPTIC TREATMENT IN PREGNANCY ON PERINATAL OUTCOME IN CROATIA - A SINGLE-CENTER STUDY
}

\author{
Vesna Elveđi Gašparović ${ }^{1}$, Mislav Mikuš ${ }^{1}$, Petrana Beljan ${ }^{1}$, Marta Živković ${ }^{2}$ \\ Klara Živković ${ }^{2}$ and Luka Matak ${ }^{3}$ \\ ${ }^{1}$ Department of Obstetrics and Gynecology, Zagreb University Hospital Centre, Zagreb, Croatia; \\ ${ }^{2}$ School of Medicine, University of Zagreb, Zagreb, Croatia; \\ ${ }^{3}$ Department of Obstetrics and Gynecology, Zadar General Hospital, Zadar, Croatia
}

\begin{abstract}
SUMMARY - Pregnancy can alter the natural course of epilepsy and affect pharmacokinetic profile of antiepileptic drugs (AEDs) making therapeutic management more demanding. Since there is no relevant population-based study in Croatia to date, we conducted this research with the aim to observe antiepileptic treatment policy in pregnancy and to determine if the number of AEDs affects pregnancy outcomes. The study included all women with epilepsy with singleton pregnancy exposed to one or more AEDs divided into two groups (group 1: one AED and group 2: more than one AED used). Data were collected retrospectively at the Department of Obstetrics and Gynecology, Zagreb University Hospital Centre, Zagreb, Croatia, and included 153 women from January 2010 to December 2018. Primary outcomes included rates of preterm delivery, major fetal malformations, gestational hypertension, cesarean section rate, and appearance of seizures during pregnancy. We found higher rates of all pregnancy complications examined than in the general population, while comparison of the two study groups yielded significant differences. Preterm labor was detected in $30 \%$ of deliveries in polytherapy group compared to $16.6 \%$ in monotherapy group $(\mathrm{p}=0.03)$. Gestational hypertension was recorded in $20 \%$ of women in polytherapy group ws. $4.90 \%$ in monotherapy group ( $p=0.009$ ). There was also a high rate of cesarean deliveries in polytherapy group (27.5\%). Seizures during pregnancy occurred in $48.4 \%$ of patients in polytherapy group, which was significantly higher than the rate recorded in monotherapy group $(\mathrm{p}=0.015)$. In this single-center retrospective study, women with epilepsy using AEDs during pregnancy had a higher rate of gestational hypertension and preterm delivery than the general population of pregnant women. To the best of our knowledge, this is the first study in Croatia observing antiepileptic treatment policy in pregnancy with regards to AED regimen and perinatal outcome.
\end{abstract}

Key words: Pregnancy; Epilepsy; Antiepileptic drugs; Gestational hypertension; Preterm delivery

\section{Introduction}

Epilepsy is the most common chronic neurological condition characterized by recurrent and transient central nervous system dysfunction, affecting 50 million

Correspondence to: Mislav Mikuš, MD, Department of Obstetrics and Gynecology, Zagreb University Hospital Centre, Petrova 13, HR-10000 Zagreb, Croatia

E-mail: m.mikus19@gmail.com

Received September 26, 2019, accepted March 8, 2020 people around the world and approximately 40,000 women in Croatia annually ${ }^{1,2}$. Approximately $40 \%$ of women with epilepsy (WWE) are in reproductive age with a prevalence of the disease in pregnancy of $0.3 \%$ $0.5 \%{ }^{3}$. Antiepileptic drugs (AEDs) are the most common teratogenic drugs prescribed to women in reproductive age ${ }^{4,5}$, with the risk specially increased for valproic acid and polytherapy ${ }^{6}$. Pregnancy can alter the natural course of epilepsy and affect pharmacokinetic profile of AEDs making therapeutic management 
Table 1. Differences in primary outcomes, seizure episodes during pregnancy and valproate usage in women with epilepsy using one or more antiepileptic drugs during pregnancy

\begin{tabular}{|l|l|l|l|l|l|l|}
\hline \multirow{2}{*}{ Primary outcome (No/Yes) } & \multicolumn{3}{l|}{ Monotherapy } & \multicolumn{2}{l|}{ Polytherapy } & \multirow{2}{*}{ p } \\
\cline { 3 - 7 } & n & $\%$ & n & $\%$ & \\
\hline Gestational hypertension & No & 77 & $95.1 \%$ & 32 & $80.0 \%$ & \multirow{2}{*}{0.009} \\
& Yes & 4 & $4.9 \%$ & 8 & $20.0 \%$ & \\
\hline Preterm labor & No & 70 & $86.4 \%$ & 28 & $70.0 \%$ & \multirow{2}{*}{0.030} \\
& Yes & 11 & $13.6 \%$ & 12 & $30.0 \%$ & \\
\hline Major fetal malformations & No & 78 & $96.3 \%$ & 40 & $100.0 \%$ & \multirow{2}{*}{0.218} \\
& Yes & 3 & $3.7 \%$ & 0 & $0.0 \%$ & \\
\hline Elective cesarean section & No & 73 & $90.1 \%$ & 29 & $72.5 \%$ & \multirow{2}{*}{0.012} \\
& Yes & 8 & $9.9 \%$ & 11 & $27.5 \%$ & \\
\hline Seizure episodes during & No & 51 & $76.1 \%$ & 16 & $51.6 \%$ & \multirow{2}{*}{0.015} \\
pregnancy & Yes & 16 & $23.9 \%$ & 15 & $48.4 \%$ & \\
\hline Valproate usage & No & 69 & $85.2 \%$ & 23 & $57.5 \%$ & \multirow{2}{*}{0.001} \\
& Yes & 12 & $14.8 \%$ & 17 & $42.5 \%$ & \\
\hline
\end{tabular}

more demanding 7 . According to some populationbased cohort studies, the incidence of epilepsy in pregnant women is as high as $0.7 \%{ }^{8}$, with ten-times higher maternal mortality in WWE than in those without the disorder, most of which is presumably due to sudden unexpected death in epilepsy (SUDEP) ${ }^{9}$. Although the use of AED during pregnancy is associated with major fetal congenital malformations and long-term cognitive and/or motor impairments, continuous drug treatment is important to control seizures which can have deleterious effects on the mother and the fetus ${ }^{1,10}$.

Since there is no relevant population-based study in Croatia to date, we conducted this research with the aim to observe antiepileptic treatment policy in pregnancy and to determine if the number of AEDs affects pregnancy outcomes.

\section{Patients and Methods}

The study included all women with epilepsy and singleton pregnancy exposed to one or more AEDs, who gave birth at the Department of Obstetrics and Gynecology, Zagreb University Hospital Centre, Zagreb, Croatia, from January 2010 to December 2018. Data were collected retrospectively by a combination of manual and electronic evaluation of clinical charts. The study included 153 women and was approved by the Department of Obstetrics and Gynecology, Zagreb University Hospital Centre Ethics Committee.
Maternal epilepsy was not classified according to seizure type, epilepsy type and epilepsy syndrome. We considered all WWE admitted during the abovementioned period and divided them into two groups of WWE taking one AED and WWE on multiple antiepileptic therapy. Women who had any complications regarding pre-existing medical condition other than epilepsy, fetal structural or chromosomal abnormalities and twins were excluded from the study. The diagnosis of maternal epilepsy was based on previous medical history and medical charts, and was previously estimated by a neurologist. Because of the retrospective nature of the study, there was no consensus about diagnostic criteria.

The primary outcomes included rates of preterm delivery (delivery before 37 complete weeks of gestation), major fetal malformations (gestational structural abnormality of medical, surgical and aesthetic importance), gestational hypertension (new onset of hypertension defined as blood pressure $\geq 140 / 90 \mathrm{~mm} \mathrm{Hg}$ after 20 weeks of gestation in the absence of proteinuria), cesarean section rate, and appearance of seizures during pregnancy. To note, other gestational hypertensive disorders such as preeclampsia did not occur in our cohort, so it was excluded from analysis.

\section{Statistical analysis}

The SPSS 17.0 for Windows (SPSS Inc., Chicago, IL, U.S.) statistical software was used on data analyses. 
Baseline demographic data were expressed as mean \pm standard deviation and median. Categorical variables were compared using the $\chi^{2}$-test. The level of statistical significance was set at $\mathrm{p}<0.05$.

\section{Results}

During the study period, 28,644 pregnancies were recorded in our database. A total of 153 singleton pregnant women diagnosed with epilepsy and exposed to AED were enrolled, accounting for $0.53 \%$ of all deliveries. The mean maternal age was $30.17 \pm 4.6$ years, range $17-43$ years.

At our hospital, the number of WWE increased significantly from 2010 to 2018 (0.22\% in 2010 to $0.65 \%$ in 2018). Interestingly, no other comorbidities such as depression and other psychiatric disorders were diagnosed in WWE during the study.

Study results are shown in Table 1 comparing primary outcomes between monotherapy and polytherapy groups. Table 2 illustrates distribution of AED usage in our cohort, and even variations between the same generic name and their respective combinations used. There were $21 \%$ of WWE that were not treated with AED during pregnancy during the study period and they were not enrolled in the study. Only 53\% (81 out of 153 patients) of WWE from our cohort were treated with a single AED, whereas four (2.6\%) patients received four AEDs during pregnancy.

Twelve different AEDs were prescribed to WWE during the 8-year study period (Table 2). These included levetiracetam, lamotrigine, oxcarbazepine, carbamazepine, valproate sodium, clonazepam, methylphenobarbital, pregabalin, clobazam, zonisamide, topiramate and ethosuximide.

Among 81 patients on monotherapy, the most commonly used AEDs were levetiracetam (LEV) ( $\mathrm{n}=22$; $27.3 \%)$, lamotrigine (LTG) (n=19; 23.5\%), oxcarbamazepine $(\mathrm{n}=14 ; 17.3 \%)$, carbamazepine $(\mathrm{CBZ})(\mathrm{n}=13$; $16.0 \%)$ and valproate sodium (VPA) $(n=7 ; 8.6 \%)$. Other drugs used as monotherapy were clonazepam, methylphenobarbital and ethosuximide (Table 3). There were 40 patients on polytherapy, with LEV + VPA as the most common combination (17.5\%). It is important to emphasize that $42.5 \%$ of our polytherapy cohort used VPA ( $\mathrm{p}=0.001)$ in combination with LEV, LTG or even with older AEDs such as phenytoin (Table 2).

We found a higher rate of all pregnancy complications examined than in the general population and sig-
Table 2. Antiepileptic drug usage in study cohort with their respective combinations in polytherapy group

\begin{tabular}{|c|c|c|}
\hline \multirow{2}{*}{ Antiepileptic drug } & \multicolumn{2}{|c|}{ Monotherapy } \\
\hline & $\mathrm{n}$ & $\%$ \\
\hline Keppra (levetiracetam) & 14 & 17.3 \\
\hline Tegretol & 13 & 16.0 \\
\hline Trileptal & 13 & 16.0 \\
\hline Lamictal & 12 & 14.8 \\
\hline Depakine & 7 & 8.6 \\
\hline Lamal (lamotrigine) & 6 & 7.4 \\
\hline Nirval (levetiracetam) & 6 & 7.4 \\
\hline Phemiton & 4 & 4.9 \\
\hline Lyvam (levetiracetam) & 2 & 2.5 \\
\hline Ethosuximide & 1 & 1.2 \\
\hline Arvind (lamotrigine) & 1 & 1.2 \\
\hline Oxalept & 1 & 1.2 \\
\hline \multirow[t]{3}{*}{ Rivotril } & 1 & 1.2 \\
\hline & \multicolumn{2}{|c|}{ Polytherapy } \\
\hline & $\mathrm{n}$ & $\%$ \\
\hline Keppra + Depakine & 7 & 17.5 \\
\hline Trileptal + Lamictal & 6 & 15.0 \\
\hline Trileptal + Keppra & 4 & 10.0 \\
\hline Depakine + Arvind & 3 & 7.5 \\
\hline Lamictal + Nirval & 3 & 7.5 \\
\hline Keppra + Topamax & 3 & 7.5 \\
\hline $\begin{array}{l}\text { Trileptal + Lamal + Pregabalin + } \\
\text { Rivotril }\end{array}$ & 2 & 5.0 \\
\hline $\begin{array}{l}\text { Trileptal + Depakine } \\
\text { + Lamal + Nirval }\end{array}$ & 2 & 5.0 \\
\hline Tegretol + Frisium & 2 & 5.0 \\
\hline Phemiton + Depakine & 2 & 5.0 \\
\hline Tegretol + Zonisamid + Topamax & 1 & 2.5 \\
\hline $\begin{array}{l}\text { Arvind (lamotrigine) } \\
+ \text { Lyvam (levetiracetam) }\end{array}$ & 1 & 2.5 \\
\hline Nirval + Trileptal & 1 & 2.5 \\
\hline Nirval + Trileptal + Phemiton & 1 & 2.5 \\
\hline Lamal + Depakine & 1 & 2.5 \\
\hline Tegretol + Lamal & 1 & 2.5 \\
\hline
\end{tabular}

nificant differences comparing our two groups (Table 1). Preterm labor was detected in $30 \%$ of deliveries in polytherapy group compared to $16.6 \%$ in monotherapy group $(\mathrm{p}=0.03)$. Gestational hypertension was diagnosed in $20 \%$ of women receiving two or more AEDs compared to $4.9 \%$ in monotherapy group ( $\mathrm{p}=0.009$ ). 
There was also a high rate of cesarean deliveries in polytherapy group (27.5\%). Seizures during pregnancy occurred in $48.4 \%$ of patients in polytherapy group, which was significantly higher compared to monotherapy group ( $p=0.015)$. The rate of major fetal malformations was higher in monotherapy group $(3.7 \%$ vs. $0 \% ; \mathrm{p}=0.218$ ) (Table 1). Two of three major fetal malformations occurred in patients treated with VPA solely, including neural tube defects in both cases. The third fetal major malformation observed was diaphragmatic hernia which occurred in a WWE exposed to CBZ. Fetal growth, antepartum and postpartum hemorrhage, perinatal mortality, Apgar score in $1^{\text {st }}$ and $5^{\text {th }}$ minute and neonatal intensive care unit (NICU) admission did not differ between the two groups.

\section{Discussion}

The number of WWE in our hospital increased significantly during the 8-year study period. Most of the patients were exposed to one AED and the number of drugs had an impact on pregnancy outcome.

Epilepsy affects approximately $0.3 \%-0.5 \%$ of women in childbearing age and it is the most common serious neurological condition in pregnancy ${ }^{2}$. WWE were once advised to avoid pregnancy; however, epilepsy is no longer considered a contraindication to pregnancy. WWE are nowadays advised to continue AED during pregnancy to reduce maternal and fetal trauma associated with seizures. The goal of treatment is optimal seizure control with minimal fetal exposure to AED. Antenatal exposure to AED may be associated with preterm delivery, intrauterine growth restriction, major fetal congenital malformations, dysmorphic syndromes, and defects in neurocognitive development ${ }^{11}$. The management of WWE during pregnancy is challenging regarding higher SUDEP and mortality rates, risk of seizures ${ }^{10,12,13}$, perinatal complications $^{1,14}$, and teratogenicity of AEDs ${ }^{15}$.

In this single-center retrospective study, WWE using AEDs during pregnancy had a higher rate of gestational hypertension, preterm delivery, and major fetal malformations than the general population of pregnant women. Only half of our patients were on monotherapy; in the group on polytherapy, $22 \%$ of WWE were taking two AEDs, $1.3 \%$ were taking three AEDs, and $2.6 \%$ were treated with four AEDs. Valproate sodium still accounted for an unjustifiably high propor- tion in treatment regimen in both groups. The possible explanations are its lower price compared to secondgeneration AEDs (such as levetiracetam and lamotrigine), necessity of frequent serum level monitoring of second-generation AEDs during pregnancy, which is not feasible in Croatia, and inappropriately educated primary care physicians regarding second-generation AED usage in women of childbearing age.

After determining that almost $80 \%$ of our WWE were treated with one or more AEDs, it was interesting to detect and compare whether the number of AEDs affected perinatal outcome. Large studies confirmed teratogenic risks associated with $\mathrm{AEDs}^{16-18}$. Intrauterine exposure to valproate implies a higher risk of major congenital malformations compared to other AEDs. Our study found the rate of major fetal malformations to be higher in monotherapy group and almost all major fetal malformations (2 out of 3 ) occurred in patients treated with VPA solely. Approximately $43 \%$ of our cohort used VPA in their polytherapy regimen, but with no increase in the risk of major fetal malformations. Current guidelines strongly discourage such approach ${ }^{19-21}$. Our findings suggest the higher rate of major fetal malformations in VPA monotherapy group to be dose-related, with no evidence for preconception folate supplementation to reduce that risk. All patients treated with VPA monotherapy were exposed to $>1500 \mathrm{mg}$ dose.

Exposure to AED during pregnancy is associated with an increased risk of preterm birth ${ }^{20}$. Furthermore, our study recorded such association and found a significantly increased risk of preterm birth in polytherapy group compared to monotherapy group $(p=0.03)$. The rationale was the increased number of seizures and the need for emergency termination of pregnancy $(p=0.015)$.

Considering the significantly increased prevalence of AED prescription for women in the reproductive age because of conditions other than epilepsy, such as mood disorders, chronic pain syndromes and migraine headaches, the proportion of pregnant women and fetuses exposed to AEDs may be even higher ${ }^{21}$. Interestingly, the effect of AED exposure and increased risk of preterm birth was also present among women prescribed AED for a psychiatric indication, at least suggesting that the effect may be medication associated ${ }^{22}$. We did not find such comorbidities.

The literature suggests that cesarean delivery is carried out more often in pregnant women with epilepsy 
than in pregnant women in the general population ${ }^{23}$. Our results did not follow that trend. We found a low rate of cesarean section in monotherapy group (9.90\%), but a significantly higher cesarean section rate in polytherapy group $(27.5 \% ; \mathrm{p}=0.012)$, suggesting that regarding the fear of complications during labor or fear that labor might trigger a seizure in polytherapy group of patients, obstetricians may have tended to perform elective cesarean section as a preferable course of action in managing delivery in WWE on polytherapy, even in the absence of other indications.

In pregnant WWE, the cause of any increase in seizures is not clearly understood and it seems to be multifactorial ${ }^{14}$. Pregnancy is associated with many physiological, endocrine and psychological changes, all of which may be responsible for the occurrence of seizures. Physiological changes during pregnancy alter the pharmacokinetics of AEDs, which may result in lower levels and seizure deterioration. Seizure deterioration may be attributed to multiple factors, including reduction in AED plasma concentration, changes in AED metabolism, sleep deprivation, hormonal changes, and psychological stress. Like Reisinger et al. ${ }^{24}$, we found that WWE in polytherapy group were more likely to have seizure deterioration during pregnancy than WWE on monotherapy $(48.4 \%$ vs. $23.9 \%$; $\mathrm{p}=0.015$ ). Almost $50 \%$ of women from polytherapy group had at least one seizure episode during pregnancy, indicating the importance of routine AED serum level assessment, especially for second-generation AEDs, such as LEV or LTG. In our cohort, LEV and LTG were the most frequently prescribed monotherapy agents during pregnancy.

Hypertensive pregnancy complications include multiple diagnoses with different risks and implications for fetal and maternal outcomes. Hypertensive pregnancy complications represent a major contributor to global maternal mortality ${ }^{25}$. Most previous studies found an increased risk of total hypertensive complications in WWE. Studies on the effect of specific AEDs on pregnant WWE were limited by small sample size, selection bias, and lack of detailed information on hypertensive disorders ${ }^{26}$. Our study showed that most WWE did not develop hypertensive complications, but that the gestational hypertension rate was significantly higher in polytherapy group (20\% vs. 4.9\%; $\mathrm{p}=0.009$ ).

How to safely treat pregnant WWE is an important question for which there are guidelines, but varia- tions in practice exist ${ }^{27}$. This study was conducted to better characterize how Croatian physicians address this difficult clinical question.

To the best of our knowledge, this is the first study in Croatia observing antiepileptic treatment policy in pregnancy with regards to AED regimen and perinatal outcome. The results demonstrate the first-line drug choice to be a consequence of the economic development status of the country that plays an important role in clinical decision-making process. We found the in utero exposure to AED to be associated with an increased risk of major fetal congenital malformations although folic acid supplementation at a dose of $5 \mathrm{mg}$ was prescribed to all patients. The frequency of serum level assessment of AED in our country should be more consistent. Maternal anxiety and stress, fluctuation in hormone levels, complicated pharmacokinetic changes of AED during pregnancy, and poor compliance may lead to poor control of epilepsy. Inappropriately controlled seizures can cause adverse pregnancy outcomes precipitating maternal injuries and intrauterine hypoxia.

Our results indicate that pregnancies with epilepsy, even in the referral third level center with multidisciplinary care and no other risk factors are still significantly associated with a higher rate of adverse perinatal outcomes.

\section{References}

1. Viale L, Allotey J, Cheong-See F, Arroyo-Manzano D, Mccorry $\mathrm{D}$, Bagary $\mathrm{M}$, et al. Epilepsy in pregnancy and reproductive outcomes: a systematic review and meta-analysis. Lancet. 2015;386(10006):1845-52. doi: https://doi.org/10.1016/ S0140-6736(15)00045-8

2. Leach JP, Smith PE, Craig J, Bagary M, Cavanagh D, Duncan $\mathrm{S}$, et al. Epilepsy and pregnancy: for healthy pregnancies and happy outcomes. Suggestions for service improvements from the Multispecialty UK Epilepsy Mortality Group [Internet]. Seizure. U.S. National Library of Medicine; 2017 [cited 2019 May 04]. Available from: https://www.ncbi.nlm.nih.gov/pubmed/28641176; doi: https://doi.org/10.1016/j.seizure.2017. 05.004

3. Viinikainen K, Heinonen S, Eriksson K, Kalviainen R. Community-based, prospective, controlled study of obstetric and neonatal outcome of 179 pregnancies in women with epilepsy. Epilepsia. 2006;47(1):186-92. doi: https://doi.org/10.1111/ j.1528-1167.2006.00386.x

4. Tomson T, Battino D, Bonizzoni E, Craig J, Lindhout D, Sabers $\mathrm{A}$, et al. Dose-dependent risk of malformations with anti- 
epileptic drugs: an analysis of data from the EURAP epilepsy and pregnancy registry. Lancet Neurol. 2011;10(7):609-17. doi: https://doi.org/10.1016/S1474-4422(11)70107-7

5. Hill DS, Wlodarczyk BJ, Palacios AM, Finnell RH. Teratogenic effects of antiepileptic drugs [Internet]. Expert review of neurotherapeutics. U.S. National Library of Medicine; 2010 [cited 2019 May 10]. Available from: https://www.ncbi.nlm. nih.gov/pubmed/20518610; doi: https://doi.org/10.1586/ ern.10.57

6. Ban L, Fleming KM, Doyle P, Smeeth L, Hubbard RB, Fiaschi $\mathrm{L}$, et al. Congenital anomalies in children of mothers taking antiepileptic drugs with and without periconceptional high dose folic acid use: a population-based cohort study. Plos One. 2015 Jun;10(7). doi: https://doi.org/10.1371/journal.pone. 0131130

7. Morrell MJ. Epilepsy in women [Internet]. American Family Physician. U.S. National Library of Medicine; 2002 [cited 2019 May 10]. Available from: https://www.ncbi.nlm.nih.gov/pubmed/12408423; doi: https://doi.org/10.1046/j.1535-7597. 2002.00017.x

8. Katz O, Levy A, Wiznitzer A, Sheiner E. Pregnancy and perinatal outcome in epileptic women: a population-based study. J Matern Fetal Neonatal Med. 2006;19(1):21-5. doi: http:// dx.doi.org/10.1080/14767050500434096

9. Edey S, Moran N, Nashef L. SUDEP and epilepsy-related mortality in pregnancy. Epilepsia. 2014;55(7). doi: https://doi. org/10.1111/epi.12621

10. Veroniki AA, Cogo E, Rios P, Straus SE, Finkelstein Y, Kealey $\mathrm{R}$, et al. Comparative safety of anti-epileptic drugs during pregnancy: a systematic review and network meta-analysis of congenital malformations and prenatal outcomes [Internet]. BMC Medicine. BioMed Central; 2017 [cited 2019 Jun 18]. Available from: https://www.ncbi.nlm.nih.gov/pubmed/28472982; doi: https://doi.org/10.1186/s12916-017-0845-1

11. Patel SI, Pennell PB. Management of epilepsy during pregnancy: an update. Ther Adv Neurol Disord. 2015;9(2):118-29. doi: https://dx.doi.org/10.1177\%2F1756285615623934

12. Sveberg L, Svalheim S, Taubøll E. The impact of seizures on pregnancy and delivery. Seizure. 2015;28:35-8. doi: https://doi. org/10.1016/j.seizure.2015.02.020

13. Nashef L, Richardson MP. Introduction. Epilepsy Research UK Expert Workshop 2014. Epilepsia. 2016;57:1-3. doi: https://doi.org/10.1111/epi.13238

14. Razaz N, Tomson T, Wikström A-K, Cnattingius S. Association between pregnancy and perinatal outcomes among women with epilepsy [Internet]. JAMA Neurol. 2017 [cited 2019 May 19]. Available from: https://www.ncbi.nlm.nih.gov/pubmed/ 28672292; doi: https://doi.org/10.1001/jamaneurol.2017.1310

15. Tomson T, Landmark CJ, Battino D. Antiepileptic drug treatment in pregnancy: changes in drug disposition and their clinical implications. Epilepsia. 2013;54(3):405-14. doi: https:// doi.org/10.1111/epi.12109
16. Soontornpun A, Choovanichvong T, Tongsong T. Pregnancy outcomes among women with epilepsy: a retrospective cohort study. Epilepsy Behav. 2018;82:52-6. doi: https://doi.org/ 10.1016/j.yebeh.2018.03.001

17. Helmers SL, Thurman DJ, Durgin TL, Pai AK, Faught E. Descriptive epidemiology of epilepsy in the U.S. population: a different approach. Epilepsia. 2015;56(6):942-8. doi: https:// doi.org/10.1111/epi.13001

18. Lin H-L, Chen Y-H, Lin H-C, Lin H-C. No increase in adverse pregnancy outcomes for women receiving antiepileptic drugs. J Neurol. 2009;256(10):1742-9. doi: https://doi.org/ $10.1007 / \mathrm{s} 00415-009-5222-3$

19. Mawer G, Briggs M, Baker G, Bromley R, Coyle H, Eatock J, et al. Pregnancy with epilepsy: obstetric and neonatal outcome of a controlled study. Seizure. 2010;19(2):112-9. doi: https:// doi.org/10.1016/j.seizure.2009.11.008

20. Menon S, Fodjo JNS, Weckhuysen S, Bhwana D, Njamnshi AK, Dekker M, et al. Women with epilepsy in sub-Saharan Africa: a review of the reproductive health challenges and perspectives for management. Seizure. 2019;71:312-7. doi: https:// dx.doi.org/10.4314\%2Fahs.v12i2.17

21. Hernández-Díaz S, McElrath TF, Pennell PB, Hauser WA, Yerby M, Holmes LB, et al. Fetal growth and premature delivery in pregnant women on antiepileptic drugs [Internet]. Ann Neurol. U.S. National Library of Medicine; 2017 [cited 2019 Apr 12]. Available from: https://www.ncbi.nlm.nih.gov/ pubmed/28856694; doi: https://doi.org/10.1002/ana.25031

22. Kilic D, Pedersen H, Kjaersgaard MIS, Parner ET, Vestergaard M, Sørensen MJ, et al. Birth outcomes after prenatal exposure to antiepileptic drugs - a population-based study. Epilepsia. 2014;55(11):1714-21. doi: https://dx.doi.org/10.1136\%2Fbmj open-2016-012836

23. Vajda FJE, O’Brien TJ, Graham JE, Hitchcock AA, Kuhn RJP, Lander CM, et al. Cesarean section in Australian women with epilepsy [Internet]. Epilepsy Behav. U.S. National Library of Medicine; 2018 [cited 2019 Jun 5]. Available from: https:// www.ncbi.nlm.nih.gov/pubmed/30414529; doi: https://doi. org/10.1111/ane.12965

24. Reisinger T, Newman M, Loring D, Pennell P, Meador K. Antiepileptic drug clearance and seizure frequency during pregnancy in women with epilepsy. Epilepsy Behav. 2013;29(1):138. doi: https://doi.org/10.1016/j.yebeh.2013.06.026

25. Say L, Chou D, Gemmill A, Tunçalp Ö, Moller A-B, Daniels $\mathrm{J}$, et al. Global causes of maternal death: a WHO systematic analysis. Lancet Global Health. 2014;2(6). doi: https://doi. org/10.1016/S2214-109X(14)70227-X

26. Danielsson KC, Borthen I, Morken N-H, Gilhus NE. Hypertensive pregnancy complications in women with epilepsy and antiepileptic drugs: a population-based cohort study of first pregnancies in Norway. BMJ Open. 2018;8(4). doi: https://doi. org/10.1136/bmjopen-2017-020998

27. George IC, Bartolini L, Ney J, Singhal D. Differences in treatment of epilepsy in pregnancy. Neurol Clin Pract. 2019;9(3): 201-7. doi: https://doi.org/10.1212/CPJ.0000000000000642 
Sažetak

\title{
UČINAK LIJEČENJA ANTIEPILEPTICIMA U TRUDNOĆI NA PERINATALNE ISHODE U REPUBLICI HRVATSKOJ - ISKUSTVO JEDNOG CENTRA
}

\author{
V. Elveđi Gašparović, M. Mikuš, P. Beljan, M. Živkoviç, K. Živković i L. Matak
}

Trudnoća može izmijeniti prirodni tijek epilepsije i utjecati na farmakokinetiku antiepileptika (AED), što dodatno otežava liječenje. Budući da do danas u Hrvatskoj ne postoji relevantno populacijsko istraživanje, proveli smo istraživanje s ciljem promatranja načina primjene AED-a u trudnoći i utvrđivanja utječe li broj primijenjenih AED-a na ishode trudnoće. Istraživanje je obuhvatilo sve žene s epilepsijom i jednoplodnom trudnoćom izložene jednom ili više AED-a podijeljenih u dvije skupine (1. skupina: monoterapija i 2. skupina: politerapija). Podaci su prikupljeni retrospektivno u Klinici za ženske bolesti i porode KBC Zagreb i pritom su uključene 153 žene od siječnja 2010. do prosinca 2018. godine. Primarni ishodi uključivali su stope prijevremenih porođaja, velike fetalne malformacije, gestacijsku hipertenziju, stopu carskog reza i pojavu epileptičkih napadaja tijekom trudnoće. Pronašli smo veću stopu svih ispitivanih komplikacija u trudnoći nego u općoj populaciji, dok je usporedba dviju ispitivanih skupina pokazala značajne razlike. Prijevremeni porođaj otkriven je u 30\% porođaja u skupini koja je primala politerapiju u usporedbi sa $16,6 \%$ u skupini koja je primala monoterapiju ( $\mathrm{p}=0,03)$. Gestacijska hipertenzija zabilježena je u 20\% žena u skupini koja je primala politerapiju u odnosu na 4,90\% u skupini koja je primala monoterapiju $(\mathrm{p}=0,009)$. Također je bila visoka stopa porođaja dovršenih carskim rezom u skupini koja je primala politerapiju (27,5\%). Napadaji tijekom trudnoće dogodili su se u 48,4\% bolesnica u skupini koja je primala politerapiju, što je bilo značajno više od stope zabilježene u skupini koja je primala monoterapiju $(\mathrm{p}=0,015)$. Zaključno, žene s epilepsijom koje su primale AED tijekom trudnoće imale su veću stopu gestacijske hipertenzije i prijevremenih porođaja u usporedbi s općom populacijom trudnica. Prema dosadašnjim spoznajama, ovo je prvo istraživanje u Hrvatskoj koje promatra obrasce antiepileptičkog liječenja u trudnoći s obzirom na režim AED i perinatalni ishod.

Ključne riječi: Trudnoća; Epilepsija; Antiepileptici; Gestacijska hipertenzija; Prijevremeni porođaj 